\title{
Marketing the Rlamath Falls Geothermal District Heating system
}

\author{
Revin Rafferty
}

\section{June 1993}

\section{DISCLAIMER}

This report was prepared as an account of work sponsored by an agency of the United States Government. Neither the United States Government nor any agency thereof, nor any of their employees, makes any warranty, express or implied, or assumes any legal liability or responsibility for the accuracy, completeness, or usefulness of any information, apparatus, product, or process disclosed, or represents that its use would not infringe privately owned rights. Reference herein to any specific commercial product, process, or service by trade name, trademark, manufacturer, or otherwise does not necessarily constitute or imply its endorsement, recommendation, or favoring by the United States Government or any agency thereof. The views and opinions of authors expressed herein do not necessarily state or reflect those of the United States Government or any agency thereof. 


$$
D O E / I D / 13040 \cdots T / 9
$$

\author{
Marketing the Klamath Falls \\ Geothermal District Heating system
}

Prepared For:
U.S. Department of Energy
Idaho Operations office
785 DOE Place
Idaho Falls, ID 83401

Contract No. DE-FG07-90ID 13040

Prepared By:

Kevin Rafferty, P.E.

Geo-Heat Center

oregon Institute of Technology

3201 Campus Drive

Klamath Falls, OR 97601 
This report was prepared with the support of the U.S. Department of Energy (DOE Grant No. DE-FG07-90ID 13040). However, any opinions, findings, conclusions, or recommendations expressed herein are those of the author(s) and do not necessarily reflect the view of DOE. 
Marketing the Klamath Falls

Geothermal District Heating System

The Klamath Falls Geothermal District Heating system was completed in 1981. Due to the concerns of existing local well owners, a city ordinance was passed in June 1981 which effectively prevented the system from operating. A great deal of aquifer research was conducted and the system finally entered into "test" operation in 1984. After approximately 1 1/2 years of operation, leaks began to appear in the closed loop portion of the distribution piping and by February 1986 the system had to be shut down. Litigation dragged on until 1990 when a settlement was made which provided partial funding for replacement of the failed piping. These funds together with a loan from the oregon Department of Energy provided for system repairs and by early 1991 the system was again online.

Until 1992, there was no formal marketing plan for the system. This lack of marketing and the system history of poor availability combined to reduce or eliminate interest in connecting on the part of local building owners. At the time, it served only the original 14 government (state, federal and local) buildings connected at start up (1981). The revenue from these buildings, however, did not cover the entire cost of operating the system. As a result, the city was faced with a difficult decision--develop the revenue required to make the system self-supporting or shut it down.

As a result of this situation, a marketing strategy for the system was developed. The strategy was designed to address the following major issues:

- $\quad$ Rates
- $\quad$ Fintomer Retrofit cost
- System Reliability
- City Creditability
Manpower Requirements

\section{Rates}

One of the issues which the strategy had to deal with was competition with low natural gas rates. These rates, as low as $\$ 0.34$ per therm, provided a formidable barrier to geothermal market penetration. When the geothermal system was first installed, the plan was to equip each customer with an energy (Btu) meter with billing based upon geothermal at a percentage of natural gas. The savings for the customer resulted from two considerations: 1) the cost difference between gas and geothermal, and 2) the efficiency losses in the gas-fired system. Of the two, the savings due to efficiency losses in the gas system provides the largest benefit. For example, consider gas priced at $\$ 0.40$ per therm and geothermal 
at $\$ 0.32$ per therm ( $80 \%$ of natural gas). Assuming the owners present gas system operates at $60 \%$ efficiency, his actual cost of gas heat is $\$ 0.67$ per therm. In other words, geothermal could provide him with a $52 \%$ reduction in heating costs (\$0.32 vs $\$ 0.67$ ).

Unfortunately, the average building owner is under the impression that his gas system operates at efficiencies of $75 \%-85 \%$. As a result, convincing the owner of his potential savings boils down to haggling over the existing system efficiency. This is a difficult task.

In order to avoid this, the new strategy eliminates the use of energy meters in favor of a flat rate billing approach. The flat rate approach has several benefits. Most importantly, it is simple. The rate is negotiable but for most customers approximates $50 \%$ of the gas bill. Building owners understand this. In addition, use of the flat rate reduces the customer retrofit cost since it is no longer necessary to buy a meter. Finally, the flat rate is a guaranteed value for the first 10 years of the contract. There is no inflation in the cost for the customer.

The flat rate is based upon historic fuel bills for the building. This data, for the previous 2 - 3 years, is weather normalized using a computer spreadsheet developed especially for this purpose (Appendix A). The average annual value is then used for calculating the annual geuthermal cost. The city is flexible in terms of its payment schedule with the customer (12 months, 6 months, lump sum, etc.).

\section{Customer Retrofit Costs}

Retrofit costs for the size buildings in the downtown area can be a problem. Many buildings do not have hot water heating systems. As a result, connection to the district requires the installation of new terminal equipment.

The original requirements (1981) called for the installation of customer heat exchangers at each building. For buildings without existing hot water systems, this approach also requires a circulating pump, expansion tank, cross connection to city water, pressure reducing valve and all the components necessary to accommodate a closed loop in the building. In larger buildings, the cost of these components is not a significant part of th project cost. For small buildings, however, the costs are a much greater percentage of the total costs due to the smaller number of terminal units.

To reduce retrofit costs, the new marketing plan eliminates the requirement for a customer heat exchanger. New customers are now connected directly into the distribution system with district loop water used as the building heating medium. This eliminates all of the above mentioned components with the exception of the circulating pump. In some of the smallest buildings, even the pump can be eliminated. Coupled with the elimination of the Btu meters, this approach greatly reduces the retrofit costs for customers. 
For a customer with an $800,000 \mathrm{Btu} / \mathrm{hr}$ load served by 6 unit heaters, the elimination of these components would reduce retrofit cost by $25 \%$ (Appendix B).

\section{Financing}

Lack of sufficient revenue for the district heating system coupled with the city's tight budget situation precluded any financing program at the local level.

Fortunately, the state operates two programs which have been used in the marketing plan. The first of these is available only to taxable entities and is referred to as the Business Energy Tax credit (BETC). This program offers business a $35 \%$ tax credit on the costs associated with connection to the geothermal district heating system (retrofit, design, permits, etc.). The tax credit must be taken over 5 years $(10 \%, 10 \%, 5 \%, 5 \%, 5 \%)$ but substantially improves the outlook for those able to take advantage of it. It is a very popular program and the funds set aside by the legislature for it are committed very quickly each year. As a result, it has been necessary to concentrate marketing efforts on tax credit eligible customers during December, January and February so that applications can be forwarded to the state early enough in the year to take advantage of the BETC. State approval of the applications must be secured prior to construction.

The second state program is the Small Energy Loan Program (SELP). This program will loan the entire cost of the energy project to the customer. The program is financed by the sale of bonds with the loan terms and rate tied to the bond sale. Current terms are approximately $7-8 \%$ and 10 years.

Few if any potential customers were aware of the existence of these programs. In addition to introducing the customer to the program, assistance in filling out the applications has been provided.

\section{System Reliability}

The Klamath Falls system has not had (prior to the past few years) a particularly reliable history. Due to the political and piping issues discussed earlier, a great deal of downtime occurred. Although these problems have been solved and the system now provides a reliable energy source to the customer, advising potential customers of this is a difficult task.

These issues were discussed in several public meetings when the county threatened to remove their buildings from the system in early 1992. After much discussion, the county decided to remain with the system for the long term. This was very reassuring to many of the prospective local customers. 
For others, who remain skeptical, individual discussions in which the details of the past piping problems are clearly explained generally has proven to be an effective strategy.

\section{City Creditability}

The creditability of the seller is always subject to question from the customer prospective. In the case of the city of Klamath Falls, this has been a particular problem. In 1991, it was necessary to implement a substantial rate increase for the city's municipal water system customers. The rate increase was the subject of considerable controversy and media attention. This episode was fresh in the minds of many of the local building owners who were contacted about the geothermal system. Fortunately, time has eroded much of the bad feeling regarding the water rate increase.

More effective, however, has been the fact that once agreed upon between the city and the customer, the geothermal rate is included in the contract and guaranteed for 10 years. This precludes any possibility of the city implementing unexpected rate increases. In addition, the guaranteed flat rate is very useful for budgeting purposes. Non-profit agencies such as churches and social clubs find this especially attractive.

\section{Manpower Requirements}

One of the issues which most thwarted previous marketing of the system was a lack of manpower to do the job. The geothermal system has no staff of its own. It is supervised by an individual who also has responsibility for the waste water system as well. For the past several years, waste water regulatory issues have absorbed all of the time available leaving nothing for the geothermal system. As a result, it was necessary to identify another source of manpower for the effort.

The Geo-Heat center provides initial retrofit estimates and developed a life-cycle cost analysis for the customer evaluation (Appendix C) along with the fuel use weather normalization spreadsheet described earlier.

A local mechanical engineer was also instrumental in the evaluation of retrofits for several buildings. His volunteer efforts at the outset have been rewarded with design work as some of the larger buildings have prepared for connection to the system.

Finally, a local wood products firm provided an individual from its public relations staff to coordinate the fund drive for a line extension to the local performing arts center. The line to the theater will permit several other buildings along its route to connect to the system. A formula was developed to calculate the fee these buildings will pay to the theater for the privilege of 
connecting to the new extension (Appendix D). The publicity arising from the connection of the theater (a high profile building in the downtown area) has been very beneficial to the marketing effort.

\section{Conclusion}

The new marketing strategy for the Klamath Falls system has concentrated on offering the customer an attractive and easy to understand rate structure, reduced retrofit cost and complexity for his building along with an attractive package of financing and tax credits.

A technical evaluation of the customer's retrofit costs and savings is provided by a third party individual (either a local engineer or Geo-Heat Center staff) free to render an impartial opinion of the advantages and disadvantages. This personalized individual approach, although labor intensive, has proven to be an effective strategy.

A copy of a typical report to the customer is included as Appendix E.

\section{Results to Date}

Initial retrofit costs and 1 ife-cycle cost analysis have been conducted on 22 buildings to date. For some, the retrofit costs are simply too high for the conversion to make sense at current geothermal rates. For many, however, the prospects are good. At this writing, two new customers are now connected and operating with 5 to 8 more buildings committed to connect this construction season after line extensions are completed.

This represents nearly a $60 \%$ increase in the number of buildings connected to the system and a $40 \%$ increase in system revenue. 
Appendix A

Fuel Use Weather Normalization Spreadsheet 
Appendix B

Example Customer Cost Comparison Heat Exchanger vs.

Direct Connection 
Example customer $-800,000 \mathrm{Btu} / \mathrm{hr}$ load, 8 unit heaters, $40^{\circ} \mathrm{F} \Delta \mathrm{T}$

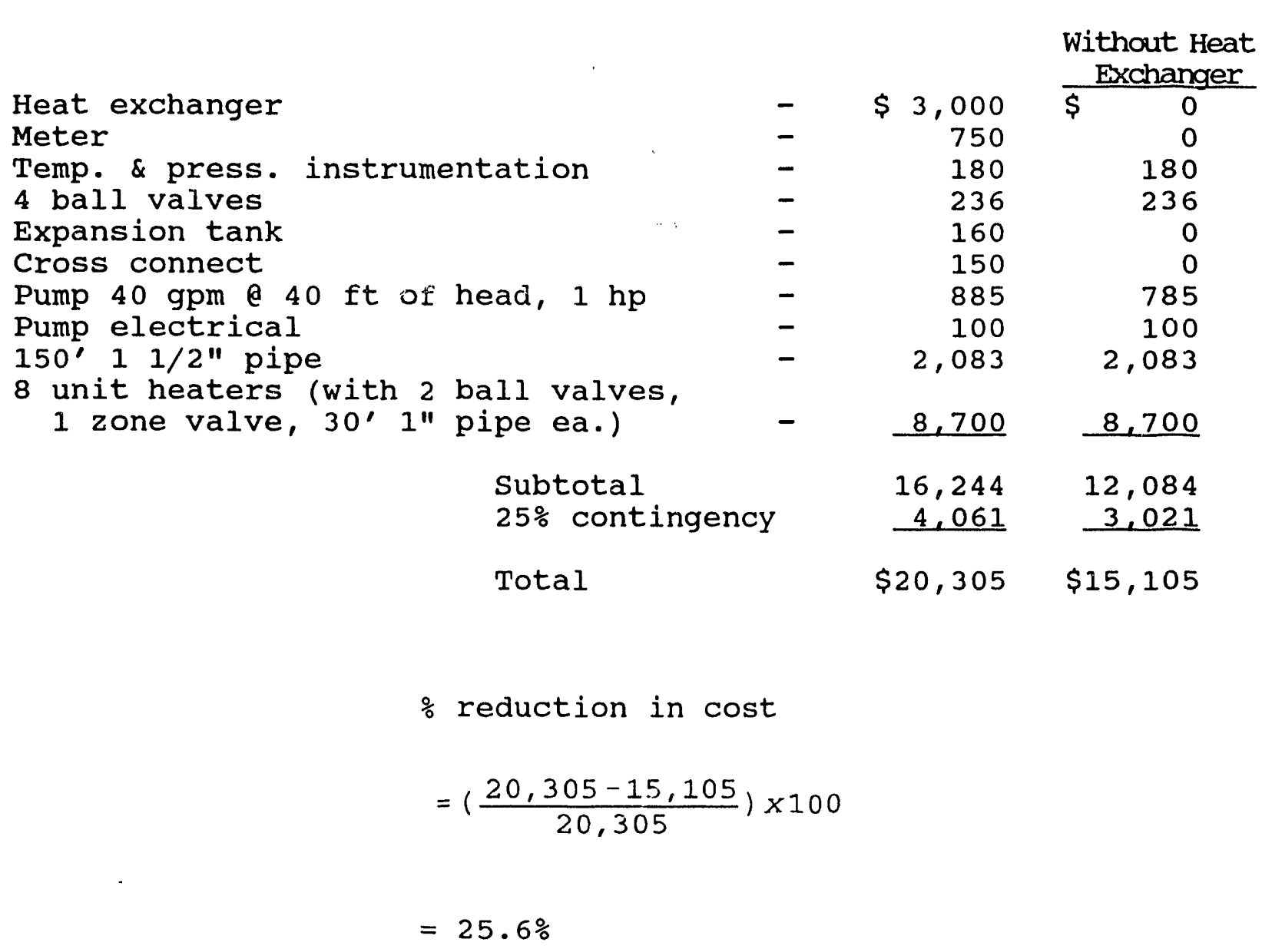

Without Heat

Exchanger

Meter

Temp. \& press. instrumentation

(1) 
Appendix C

Life Cycle Cost Analysis Spreadsheet 


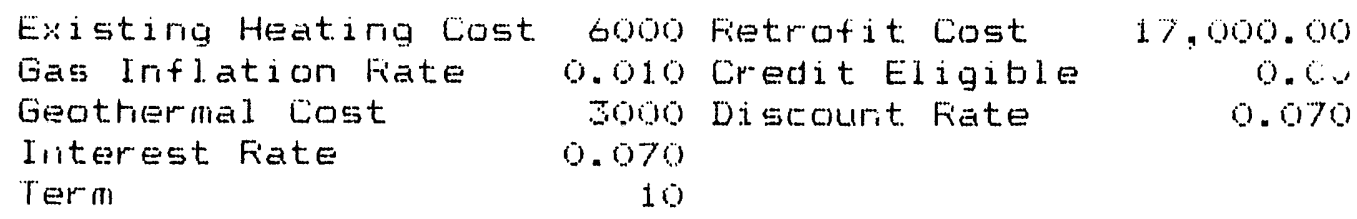

vear Nat bas Gent Tax Debt Cash Cumulative Disentcl. Cumlative Lredit Service Flow Cash Flow Cash Flow liscritd CF

\begin{tabular}{|c|c|c|c|c|c|c|c|c|}
\hline$i$ & 6000 & 3000 & 0 & 2420 & 580 & 580 & 542 & 542 \\
\hline 2 & 6060 & 3000 & 0 & 2420 & 640 & 1219 & 557 & 1100 \\
\hline$\Xi$ & 6121 & 3000 & 0 & 2420 & 700 & 1919 & 572 & 1672 \\
\hline 4 & 6182 & 5000 & 0 & 2420 & 761 & 2681 & 581 & 2253 \\
\hline 5 & 6244 & 3000 & 0 & 2420 & 823 & 3504 & 587 & 2840 \\
\hline 6 & 6306 & 3000 & 0 & 2420 & 880 & 4.390 & 590 & 3430 \\
\hline 7 & 6369 & 3000 & 0 & 2420 & 549 & 5338 & 591 & 4021 \\
\hline 8 & 6453 & 3000 & 0 & 2420 & 1012 & 6551 & 587 & 4610 \\
\hline 9 & 6497 & 3000 & 0 & 2420 & 1077 & 7427 & 586 & 5195 \\
\hline 10 & 6562 & 5000 & 0 & 2420 & 1.142 & 3569 & 580 & 5776 \\
\hline 11 & 6620 & 3314 & 0 & 0 & 3214 & 11835 & $15>4$ & 7350 \\
\hline 12 & 6694 & 3347 & 0 & 0 & 3347 & 15230 & 1496 & 88356 \\
\hline 13 & 6761 & 380 & 0 & 0 & 380 & 19610 & 1403 & 10239 \\
\hline 14 & 6829 & 3414 & 0 & 0 & 3414 & 22025 & 1324 & 11562 \\
\hline 15 & 6897 & 3448 & 0 & 0 & $344 \theta$ & 25473 & 1250 & 12815 \\
\hline 16 & 67,60 & 388 & 0 & 0 & 3483 & 28956 & 1180 & 15993 \\
\hline 17 & 7035 & 3518 & 0 & 4 & 318 & 32474 & 11.14 & 15107 \\
\hline 18 & 7106 & 3553 & 0 & 0 & 3553 & 36027 & 1051 & 16158 \\
\hline 19 & 7177 & 5588 & 0 & 0 & 5580 & 39615 & 992 & 17150 \\
\hline 20 & 7249 & $\square 624$ & 0 & 0 & 3624 & 43239 & 937 & 18087 \\
\hline
\end{tabular}


Appendix D

Pipeline Extension Cost Contribution Formula 


\section{RESOLUTION NO. 3388 \\ A RESOLUTION ESTABLISHING A REIMBURSEMENT POLICY FOR CONNECTIONS TO GEOTHERMAL \\ BRANCH LINES FINANCED PRIVATELY} WHEREAS, the City desires to encourage expansion of the
downtown hcating systcm; and WHEREAS, expansion may require extension of the main line at
private expense; and WHEREAS, to encourage such expenditure the city is willing to
provide for reimbursements against such costs from connection
charges from others who may wish to funded extension; Now THEREFORE

\section{THE CITY OF KLAMATH FALLS RESOLVES AS FOLLOWS:}

In the event an owner of property desires to connect to a privately financed geothermal main line, the City shall charge and collect a connection fee sufficient to reimburse the party who proportional share shal a fair portion of the original cost. Said shall be calculated as follows:

where:

$$
B C=M C \times \frac{B F}{F} \times \frac{B D}{I}
$$

$$
\begin{aligned}
& \text { F - branch line peak flow capacity (gpm) } \\
& B E \text { - new building peak flow requirement (gpm) } \\
& T \text { - total length of branch line (ft) } \\
& B D \text { - distance of new building from the supply end of the } \\
& \text { branch line (ft) } \\
& B C \text { - cost of main line } \\
& \text { broportional share of branch line cost for new } \\
& \text { building }
\end{aligned}
$$

Reimbursements shall be collected and paid only during the
first ten (10) years following completion Further, payments shall be made to the then of the extension. structure initially served with the extension.

Passed by the Council of the City of Klamath Falls, Oregon, this 15th day of June , 1992.

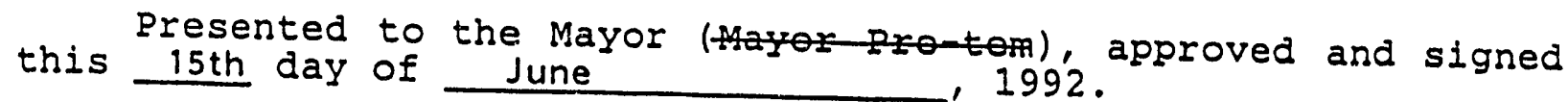

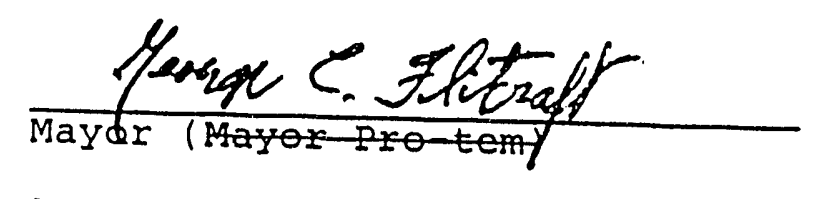

ATTEST:

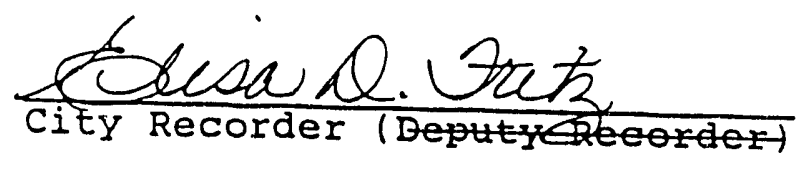


WHEREAS, to encourage such expenditure the City is willing to provide for reimbursements against such costs from connection charges from others who may wish to connect to that privately funded extension; NOW THEREFORE

THE CITY OF KLAMATH FALLS RESOLVES AS FOLLOWS:

In the event an owner of property desires to connect to a privately financed geothermal main line, the city shall charge and collect a connection fee sufficient to reimburse the party who financed the extension a fair portion of the original cost. Said proportional share shall be calculated as follows:

where:

$$
B C=M C \times \frac{B F}{F} \times \frac{B D}{I}
$$

$$
\begin{aligned}
& \text { F - branch line peak flow capacity (gpm) } \\
& \text { BE - new building peak flow requirement (gpm) } \\
& \text { L - total length of branch line (ft) } \\
& \text { BD - distance of new building from the supply end of the } \\
& \text { MC - branch line ( } f t \text { ) } \\
& \text { BC - proportional share of branch line cost for new } \\
& \quad \text { building }
\end{aligned}
$$

Reimbursements shall be collected and paid only during the first ten (10) years following completion of the extension. Further, payments shall be made to the then current owner of the structure initially served with the extension.

Passed by the Council of the City of Klamath Falls, oregon, this 15th day of June , 1992.

Presented to the Mayor (4am), approved and signed this 15th day of June , 1992.

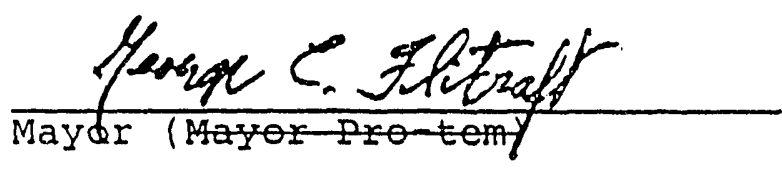

ATTEST:

STATE OF OREGON

COUNTY OE KLAMATH

CITY OF KLAMATH FAILS \}

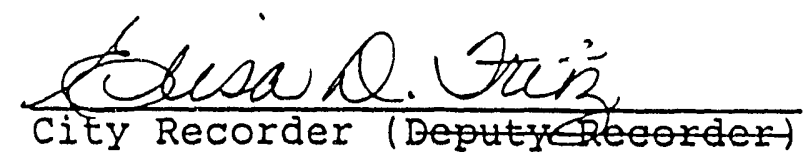

I,

Recorder (Deputy Recorder)

for the City of Klamath Falls, Oregon, do hereby certify that the foregoing is a true and correct copy of an Resolution duly adopted by the Council of the City of Klamath Falls, Oregon, at the regular meeting held on the 15 th day of thereafter approved and signed by the Mayor (Mayor Rro-tom) and attested by the City Recorder (t) Roordor). 
Appendix E

Typical Customer Evaluation Report 
April 21, 1993

Mr. Norman Jones

First Baptist Church

707 High Street

Klamath Falls, OR 97601

Dear Mr. Jones:

We have completed a preliminary review of the connection of your building to the city's geothermal system. Based on data from the gas company (1/91 to 2/93), your weather normalized annual gas cost is approximately $\$ 6000$. Retrofit of the existing heating system for connection to the district heating system is estimated to cost $\$ 10,000$ inciuding a $20 \%$ contingency factor. This factor considers only the costs associated with conversion of the building itself and for extending service lines from the city's lines in the street. The city's rate for geothermal heat is a negotiable figure; but, for many customers approximately $50 \%$ of the current natural gas bill.

Retrofit of the existing heating system consists of connecting supply and return lines, from the city system to the existing supply and return lines at the boiler. The boiler would remain in place and available as emergency backup to the geothermal system. It would be valved off during normal operation. A new control valve would be added to modulate the flow of hot water into the building and assure the system achieves a $40^{\circ}$ temperature drop. In addition to the modifications in the boiler room, supply and return lines (3") would be installed across the parking lot on the north side of the building to connect your heating system with the main lines in the street.

As I mentioned earlier, the $\$ 10,000$ figure does not consider the costs associated with extending service lines up 8 th street from their present location. These costs can be broken down into two parts: 1) the contribution to the Ross Ragland Theatre for connection to their line (at 8th and Pine), and 2) the cost for installing lines up 8 th street to the church.

The cost of the Ragland contribution is determined using a formula approved by the city council. For the church, this formula yields a value of $\$ 7,200$. The value is arrived at by ratioing the water flow required by the church to the total water flow the line can 
Mr. Norman Jones

Page 2

April 21, 1993

carry. A similar procedure for length of the line used compared to total length of the line is made. Questions regarding this cost can be addressed to Bob Kingzett at Jeld-Wen (882-3451).

The cost of lines extended up 8 th street to the building location would be best discussed with Kent Colahan at the city (883-5366). Your cost for these lines is dependent upon participation by neighboring buildings (Sacred Heart School, Sacred Heart church, American legion, St. Paul's Church).

To evaluate the costs and benefits of connecting to the system (exclusive of the as yet undefined costs described above), we have prepared two tables. Table 1 considers the case in which the entire capital cost is financed for 10 years at $7 \%$ which is similar to the terms offered through the states Small Energy Loan Program (SELP). Based on a natural gas inflation rate of $1 \%$ per year and a total heating cost of $\$ 6000$ per year, the total savings over the 20 -year period amounts to just over $\$ 43,000$.

The second case assumes the project is $100 \%$ equity financed. In this arrangement, the 20-year savings amounts to $\$ 67,000$ and yields a simply payback of approximately 6 years. Looking at it another way, the project rate of return is approximately $18 \%$.

At this point, it might be useful to contact the city and discuss geothermal rates and the costs associated with installation of service lines. If you have any questions, please don't hesitate to contact us.

sincerely,

Kevin Rafferty, P.E. Research Associate

$\mathrm{KR} / \mathrm{dg}$ 
CPEHITSTF:

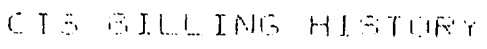

4,153

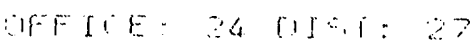

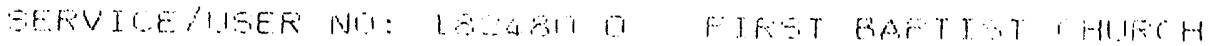

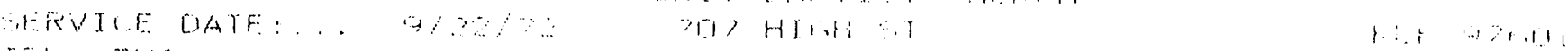

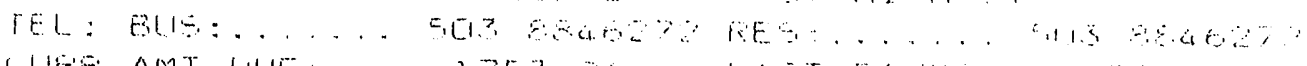

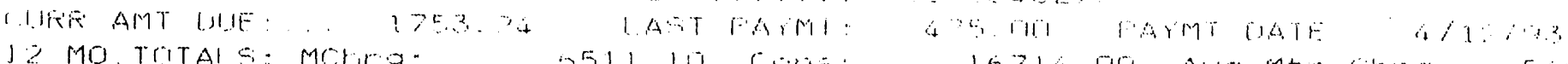

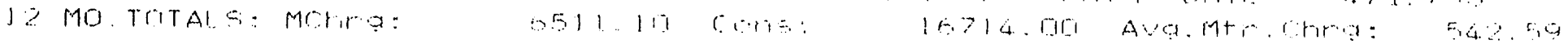

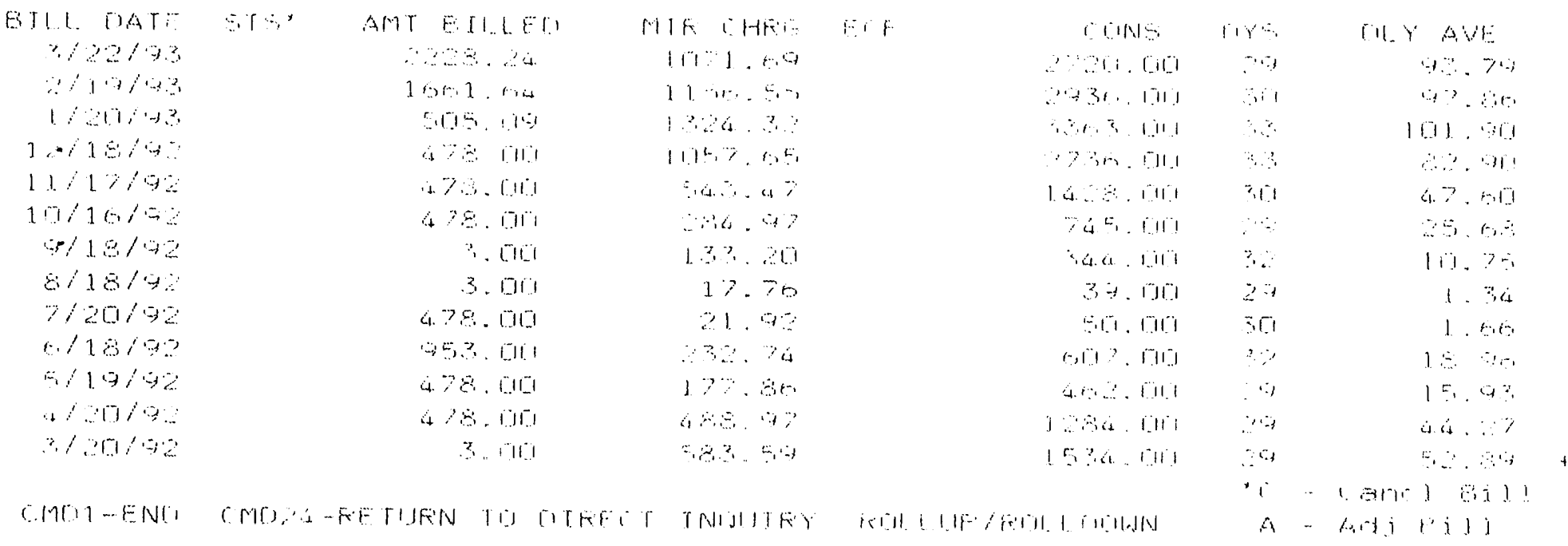

$4 / 5193$ Ftipe this helpo. If whes an be if funther assistance, pleare let us tran.

Doun 


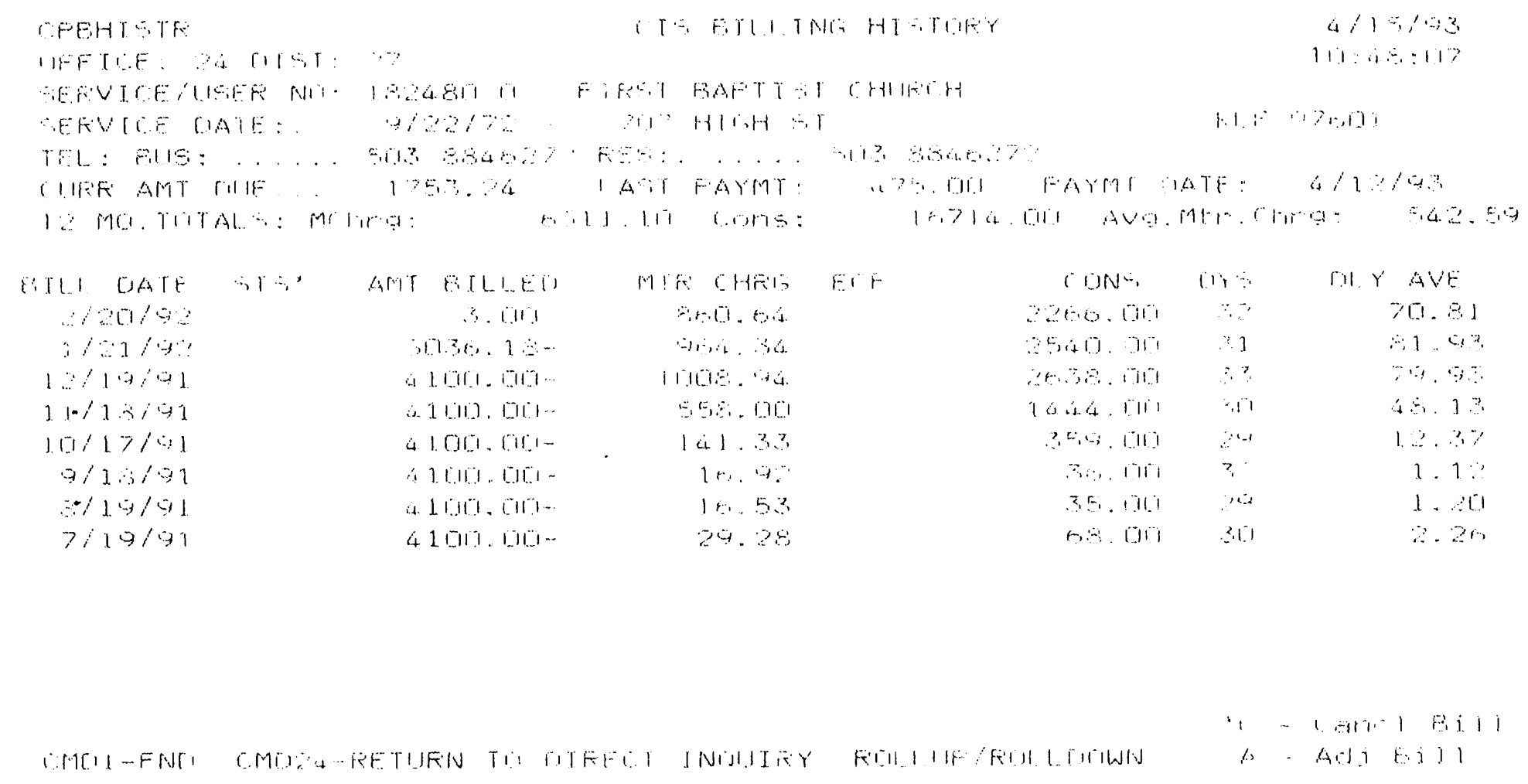


First Buptiot

$\begin{array}{rrr}91 & & \\ 0 D & \text { actual } & \text { corrected } \\ 1057 & 0 & 0 \\ 688 & 0 & 0 \\ 895 & 0 & 0 \\ 702 & 0 & 0 \\ 554 & 0 & 0 \\ 295 & 0 & 0 \\ 12 & 29 & 92 \\ 35 & 17 & 38 \\ 89 & 17 & 37 \\ 411 & 141 & 166 \\ 762 & 558 & 591 \\ 1027 & 1008 & 1032 \\ & & \\ 5515 & 1770 & 1940\end{array}$

\begin{tabular}{|c|c|c|}
\hline 52 & & \\
\hline$D O$ & actual & correc:ted \\
\hline 974 & 36.4 & 1000 \\
\hline 700 & 861 & 1010 \\
\hline 670 & 584 & 716 \\
\hline 475 & 489 & 611 \\
\hline 182 & 178 & $\Xi \theta 0$ \\
\hline $14 \dot{6}$ & $2 \because 4$ & 290 \\
\hline 50 & 22 & 15 \\
\hline 37 & 10 & 34 \\
\hline $21:$ & 13 & 121 \\
\hline 465 & 285 & 277 \\
\hline $65:$ & 54.3 & 514 \\
\hline 1201 & 1058 & 092 \\
\hline 605 & 5.96 & 696 \\
\hline
\end{tabular}

$\begin{array}{rr} & 1097 \\ & \text { actual } \\ 1000 & 1394 \\ 1090 & 1156 \\ 1 & 0 \\ 1 & 0 \\ 1 & 0 \\ 1 & 0 \\ 1 & 0 \\ 1 & 0 \\ 1 & 0 \\ 1 & 0 \\ 1 & 0 \\ 1 & 0 \\ 0 & 280\end{array}$




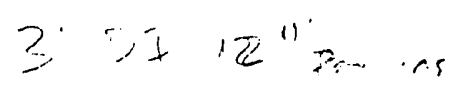

First Baptist Church-

it:

In building costs=

wall at

2. $2 \frac{1}{2}$ " gates

therm

- press

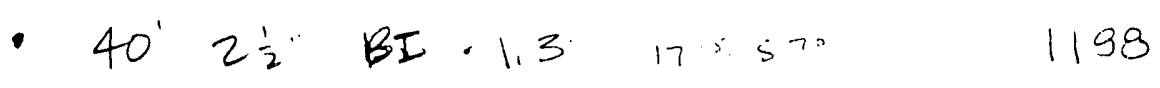

- TCV $2 \frac{1}{2}$

cut in exist ins
100

23,0

11.0

40

705

200

2573

Line to value box

trench bk fl 150' es 750

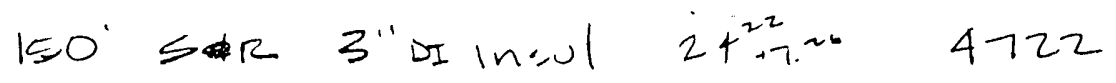

rewove paring $e 4^{*} / 4 \alpha \quad 100$

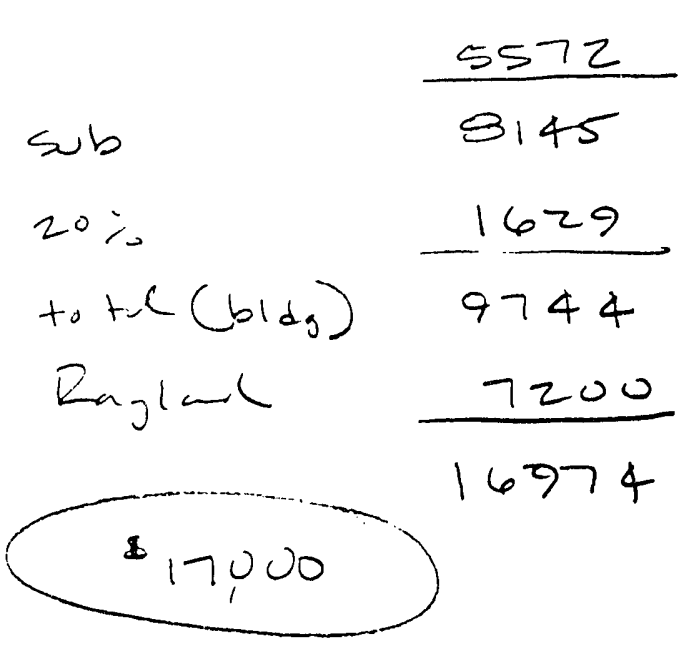




\begin{tabular}{|c|c|c|c|c|c|c|c|c|}
\hline \multirow{2}{*}{$\begin{array}{c}\cdot \\
\cdot \\
\cdot \\
\text { Year }\end{array}$} & \multicolumn{3}{|c|}{$\begin{array}{l}\text { Existirig Heating Cost } \\
\text { Gas Inflation Fate } \\
\text { Geothermal Cost } \\
\text { interest rate } \\
\text { Term }\end{array}$} & $\begin{array}{r}0000 \\
0.010 \\
5000 \\
0.070 \\
10\end{array}$ & \multicolumn{2}{|c|}{$\begin{array}{l}\text { Fetrofit Cost } \\
\text { Credit Eligible } \\
\text { Discount Fite }\end{array}$} & \multicolumn{2}{|l|}{$\begin{array}{r}1 \% .000 .00 \\
0.00 \\
0.180\end{array}$} \\
\hline & Nat Gas & Geot & $\begin{array}{r}\text { Tax } \\
\text { Credit }\end{array}$ & $\begin{array}{l}\text { Debt } \\
\text { Service }\end{array}$ & $\begin{array}{l}\text { Cash } \\
\text { Fiaw }\end{array}$ & $\begin{array}{l}\text { Cumulative } \\
\text { Cash Flow }\end{array}$ & $\begin{array}{l}\text { Discntd. } \\
\text { Cassh Flow }\end{array}$ & $\begin{array}{l}\text { Cunlative } \\
\text { Dscritd CF }\end{array}$ \\
\hline 1 & 6000 & 3000 & 0 & 2420 & 580 & 530 & 491 & 471 \\
\hline 2 & 6060 & 8000 & 0 & 2420 & 640 & 1219 & 459 & 951 \\
\hline$\exists$ & 6121 & 3000 & 0 & 2420 & 700 & 1919 & 426 & 1377 \\
\hline 4 & 6182 & 3000 & 0 & 2420 & 761 & 2681 & 393 & 1.769 \\
\hline 5 & 6244 & 3000 & 0 & 2420 & 823 & 3504 & 360 & 2129 \\
\hline io & 6306 & 3000 & 0 & 2420 & 886 & 4390 & 328 & 2457 \\
\hline 7 & 6.57 & 5000 & 0 & 2420 & 949 & 5338 & 298 & 275 \\
\hline 3 & 643 & 3000 & 0 & 2420 & 1012 & 6.551 & 269 & $\therefore 024$ \\
\hline 9 & 6497 & 3000 & 0 & 2420 & $107 \%$ & 7427 & 243 & 2067 \\
\hline 10 & 6562 & 3000 & 0 & 2420 & 1142 & 8569 & 213 & 3495 \\
\hline 11 & 6628 & 314 & 0 & 0 & 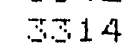 & 11983 & 5.37 & 4022 \\
\hline 12 & 6694 & 3547 & 9 & 0 & $\$ 47$ & 1. 5200 & 459 & 4481 \\
\hline 13 & 6761 & 3880 & 0 & 0 & 3880 & 18610 & 893 & 4874 \\
\hline 14 & 6829 & 3414 & 0 & 0 & 3414 & 22025 & 3.56 & 5211 \\
\hline 15 & 6897 & 3448 & 0 & 0 & 3448 & $2547=$ & 280 & 5495 \\
\hline 16 & 6960 & 3483 & 0 & 0 & 3493 & 28956 & 247 & 5745 \\
\hline 57 & 70.5 & 3518 & 0 & 0 & 516 & 32474 & 211 & 5956 \\
\hline 13 & 7106 & 3553 & 0 & 0 & 3553 & 36027 & 181 & 6137 \\
\hline 19 & 7177 & 3580 & 0 & 0 & 5588 & 39615 & 155 & 6291 \\
\hline 20 & 7249 & 3624 & 0 & 0 & 364 & 4.259 & 132 & 6424 \\
\hline
\end{tabular}




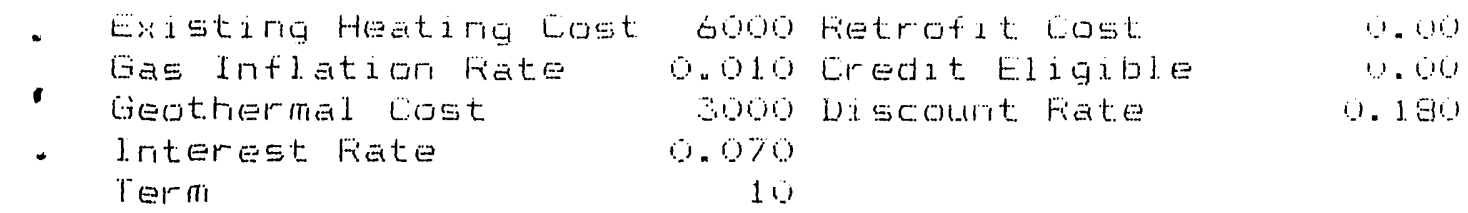

\begin{tabular}{|c|c|c|c|c|c|c|c|c|}
\hline Yent & Wat GaS & Gecit & Tax & Dett & Cash & Courrul at ive & i) is sicritd. & Cumiative \\
\hline & & & Credit & Service & Flow & Cash Flow & Cash, Flaw & Decritd QF \\
\hline 1 & 6000 & 3000 & 0 & o) & 3000 & 0000 & 2542 & 2542 \\
\hline 2 & 6060 & 3000 & 0 & 0 & 5060 & 0060 & 21.78 & 4740 \\
\hline$\because$ & 6121 & 3000 & 0 & i) & 3121 & 9101 & 1999 & 6659 \\
\hline 4 & 6132 & 5000 & 0 & 0 & 182 & 12362 & 1.641 & $82 \theta 0$ \\
\hline 5 & 624 & 5000 & 0 & 0 & 244 & 15600 & 1418 & 9698 \\
\hline 6 & 6.06 & 300 & 0 & 0 & 3006 & 19912 & 12215 & 10923 \\
\hline 7 & 6369 & 3000 & 0 & 0 & 369 & 2281 & 1058 & 11981 \\
\hline$\theta$ & 645 & 3000 & 0 & 0 & 343 & 25714 & 915 & 12894 \\
\hline 9 & 6497 & 5000 & 0 & 0 & 3477 & 29211 & 700 & 13682 \\
\hline 10 & 6062 & 3000 & o & 0 & 3562 & $27 / 3$ & $\operatorname{tos} 1$ & 14363 \\
\hline 11 & 6620 & 314 & 0 & 0 & 314 & 500 & 5.57 & 14895 \\
\hline 12 & 6694 & 347 & 0 & 0 & 347 & 394.4 & 459 & 15.56 \\
\hline 13 & 6781 & 580 & $\theta$ & 0 & 300 & 42015 & 393 & 15752 \\
\hline 1. 4 & 6829 & 5414 & 0 & a) & 3414 & 46227 & 350 & 16085 \\
\hline 15 & 0697 & $=446$ & 0 & 0 & 3449 & $496 \%$ & 20 & 16376 \\
\hline 10 & 6960 & 3485 & 0 & 0 & 383 & 53160 & $24 \%$ & 16,023 \\
\hline 17 & 70.5 & 518 & 0 & 0 & 3513 & $560 \%$ & 211 & 1.6, 64 \\
\hline 18 & 7106 & 45: & 0 & 0 & 365 & 6021 & 181 & 17014 \\
\hline 1.9 & $717 \%$ & 51583 & 0 & 0 & 563 & 6.8819 & 155 & '7'1716 \\
\hline 20 & 7249 & 3624 & c) & 0 & 624 & 67444 & $1 s$ & 17001 \\
\hline
\end{tabular}


Appendix $\mathrm{F}$

customer contract 


\section{GEOTHERMAL ENERGY CONNECTION \\ AND \\ SERVICE AGREEMENT}

THIS AGREEMENT is made this Klamath Falis, an Oregon municipal corporation, hereinafter
referred to as "CITY", and hereinafter referred to as "USER".

\section{W I T N E S S E T H} WHEREAS, CITY has rights in a geothermal well and
distribution system, hereinafter called "SYSTEM", to supply
geothermal heat to its customers; and

WHRREAS, USER is the owner of a building or structure located within the City of Klamath Falls and desires to connect to CITY's SYSTEM and receive space heating service therefrom; and

WHEREAS, by this GEOTHERMAL ENERGY CONNECTION AND SERVICE AGREEMENT, the parties intend to evidence USER's commitment to connect to the SYSTEM and to purchase geothermal heat from CITY;

NOW THEREFORE, in consideration of the promises, the mutual covenants and obligations set forth below, and other good and valuable consideration, CITY and USER hereby agree as follows:

1. Service. USER commits to connect to the SYSTEM, and to purchase geothermal heat from CITY and CITY agrees to sell geothermal heat to USER when said gcothermal heat is available.

USER agrees to abide by all rules and regulations of CITY as set forth in the attached Exhibit "A" RULES \& REGULATIONS FOR GEOTHERMAL SERVICE, as the same may be amended from time to time. Attached Exhibit "B".

2. Place of Delivery. The geothermal heat shall be delivered to USER at a point terminating at the vaive box at USER's City of Klamath Falls Oregon. in the

3: Use of Service. CITY and USER specifically agree that geothermal service as set forth in this Agreement is available at the time of execution of this Agreement.

4. Term. This Agreement shall commence on the 1st day of USER's building is connécted to ${ }^{\prime}$ or as soon thereafter as the a term of may be extended thereafter by mutual This Agreement

consent of the parties.

Subject to Installation and Maintenance of Receiving Facility. and maintain at prior plan approval, USER shall provide, furnish but not limited expense, all necessary facilities, including USER's building or structure tines, appliances and fittings within point set forth in paragraph 2 above. 
WHEKEAS, CITY has rights in a distribution system, hereinafter called "SYSTEM", to supply
geothermal heat to its customers; and

WHEREAS, USER is the owner of a building or structure located within the city of Klamath Falls and desires to connect to
CITY's SYSTEM and receive space heatjng service therefrom; and

WHEREAS, by this GEOTHERMAL ENERGY CONNECTION AND SERVICE AGREEMENT, the parties intend to evidence USER's commitment to connect to the SYSTEM and to purchase geothermal heat from CITY;

NOW THEREFORE, in consideration of the promises, the mutual covenants and obilgations set forth below, and other good
and valuable consideration, CITY and USER hereby agree as follows:

1. Service. USER commits to connect to the SYSTEM, and to purchase geothermal heat from CITY and CITY agrees to sell geothermal heat to USER when said geothermal heat is available.

USER agrees to abide by all rules and regulations of CITY as set forth in the attached Exhibit "A" RUIES \& REGULATIONS FOR GEOTHERMAL SERVICE, as the same may be amended from time to time. Attached Exhibit "B".

2. Place of Delivery. The geothermal heat shall be delivered to USER at a point terminating at the valve box at USER's City of Klamath Falls, Oregon. in the

3. Use of Service. CITY and USER specifically agree that geothermal service as set forth in this Agreement is available at
the time of execution of this Agreement.

4. Term. This Agreement shall commence on the 1st day of USER's building is conn' 19 , or as soon thereafter as the c. term of may be extended thereafter by mutual consent years. This Agreement

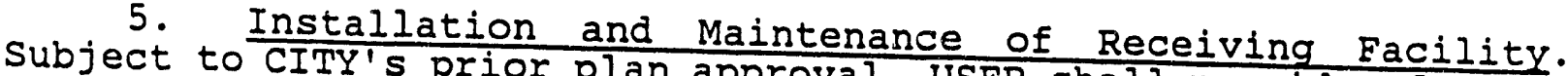
and maintain at its expense pproval, USER shall provide, furnish but not limited to, pipelines, necessary facilities, including USER's building or, pipelines, appliances and fittings within point set forth in Paragra, h 2 above.

6. Backup System. USER shall provide a backup heating system capable of providing service to its building in the event of an interruption in geothermal energy service. The USER's backup in order to minimiale of providing service on a temporary basis interruption in the supply of geothermal energy.

7. Meters and Monitoring Equipment. CITY may, in its discretion, install CITY furnished metering equipment to provide for the accurate recording of all geothermal heat consumed by USER. Meters shall be installed by CITY in the event CITY suspects heat 
is being utilized in excess of the purposes approved of under this
Agreement.

8. Connection Charge. USER shall be required to pay "he cost of extending the geothermal supply and return lines to the valve box at USER's building or structure.

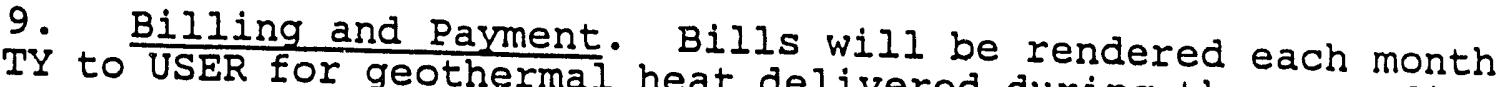
by CITY to USER for geothermal heat delivered during the preceding month, and each such bili shall be payable to the CITy on or before
the 15 th day after the date of such bill.

\begin{tabular}{c} 
10. Rates. USER shall pay the flat rate of \\
during the heating season, \\
\hline , for the term of this Agreement.
\end{tabular}

11. Interruption of Service. CITY will endeavor to provide an uninterrupted supply of geothermal heat, but in case it shall be Wholly or partially prevented from delivering geothermal heat to necessary to any force majeure or in the event CITY deems it inspecting or uspend delivery of geothermal heat for the purpose of its source of geotiring its transmission and distribution system, repairs or alternathermal heat supply or other apparatus or to make shall not be obligated to such period and shall doliver geothermal heat to USER during resulting from such inter be liable for any damage or loss failure. In the prevention, suspension or delivered to the event the temperature of the geothermal heat of heat is not availas than $F_{1}$, and/or sufficient quantity USER may USER may terminate this Agreement, but shall not claim any loss or damage resulting from the termination of service.

In the event service is interrupted for a period of twentyfour (24) hours or more, the monthly bill shall be reduced proportionately to reflect such interruption.

The extent of any liability on the part of CITY shall be as provided for in this Agreement and as set forth in Oregon Revised
Statutes, 30.270 .

12. Injury to Persons or Property. CITY shall not be responsible for the distribution, transmission, control, use or application of geothermal heat beyond the point of its delivery to USER, and shall not, in any event, be liable for damages or injury to persons or property arising, occurring or resulting in any manner from the receiving, use, application or distribution by USER of geothermal heat except for such damage or injury which shall be shown to have been occasioned by negligence of CITY, its agents or
employees.

13. Ingress and Egress. CITY shall, at all times during the continuance of this Agreement, have the right of ingress and egress at reasonable times and places to the premises of USER, for any purposes connected with the delivery, monitoring of, metering of, and/or distribution of geothermal heat hereunder, or the exercise of any rights secured to or the performance of any obligation imposed upon it by this Agreement.

14. Default. If default shall be made at any time by USEP in 
month and each suceding month, and each such bill shall be payable to the CITY on or before the 15th day after the date of such bill.

\begin{tabular}{c} 
10. Rates. USER shall pay the flat rate of \\
during the monthly \\
\hline heating season, \\
, for the term of this Agreement.
\end{tabular}

11. Interruption of Service. CITY will endeavor to provide an uninter rupted supply of geothermal heat, but in case it shall be wholly or partially prevented from delivering geothermal heat to USER, due to any force majeure or in the event CITY deems it necessary to suspend delivery of geothermal heat for the purpose of inspecting or repairing its transmission and distribution system, its source of geothermal heat supply or other apparatus or to make repairs or alternations thereon or connections therewith, then CITY shall not be obligated to deliver geothermal heat to USER during such period and shall not be liable for any damage or loss resulting from such interruption, prevention, suspension or failure. In the event the temperature of the geothermal heat delivered to USER is less than F., and/or sufficient quantity of heat is not available to meet peak demands, at USER's option, USER may terminate this Agreement, but shall not claim any loss or damage resulting from the termination of service.

In the event service is interrupted for a period of twentyfour (24) hours or more, the monthly bill shall be reduced proportionately to reflect such interruption.

The extent of any liability on the part of CITY shall be as provided for in this Agreement and as set forth in oregon Revised Statutes, 30.270 .

12. Injury to persons or Property. CITY shall not be responsible for the distribution, transmission, control, use or application of geothermal heat beyond the point of its delivery to USER, and shall not, in any event, be liable for damages or injury to persons or property arising, occurring or resulting in any manner from the receiving, use, application or distribution by USER of geothermal heat except for such damage or injury which shall be shown to have been occasioned by negligence of CITY, its agents or employees.

13. Ingress and Egress. CITY shall, at all times during the continuance of this Agreement, have the right of ingress and egress at reasonable times and places to the premises of USER, for any purposes connected with the delivery, monitoring of, metering of, and/or distribution of geothermal heat hereunder, or the exercise of any rights secured to or the performance of any obligation imposed upon it by this Agreement.

14. Default. If default shall be made at any time by USER in the payment of any sum of money due hereunder, or in the performance of any other term or condition of this Agreement, and if such default shall continue for a period of twenty (20) days, CITY shall have the right at its option, on fifteen (15) days written notice to USER, to terminate this Agreement, or at its option, without terminating or in any way voiding this Agreement, to discontinue, suspend or withdraw the delivery, furnishing or supply of geothermal heat until such default has been completely remedied. 


\title{
$\frac{\text { RULES AND REGULATIONS }}{\text { FOR }}$ GEOTHERMAL SERVICE
}

\begin{abstract}
1. These rules and regulations become a part of each and every GEOTHERMAL ENERGY CONNECTION AND SERVICE AGREEMENT
(AGREEMENT) between the City of Klamath Falls, an Oregon municipal
corporation (CITY) and users of geothermal water (USER) and changed at any time by the CITY upon due nater (USER) and may be
\end{abstract}

2. The privilege of the use of geothermal heat shall be
conditioned upon a written and signed AGREEMENT.

for any USER except upon agreement

4. Changes or altera

are not permitted during the period the USER's piping or fixtures written approval of the CITY. The USER'S AGREEMENT, except upon the requirements of the CITY at all times. System must conform to acceptable types of connection systems are attagrams illustrating purposes.

5. Upon request of CITY, CITY provided flow meters must be installed on USER's inlet piping, and meters shall be located as to provide access for convenient inspection by representatives of CITY
at reasonable hours.

6. No more than one building may be connected to any one service connection without written consent of the CITY.

7. Use of the geothermal heat is not permitted for any purpose other than that specified in Exhibit "B" to the AGREEMENT.

8. The CITY is not responsible for the efficiency of any system supplied with heat from its mains, even though the CITY
grants the approval of its installation.

9. The CITY is not responsible for damage of any kind caused by the geothermal heated water or resulting from shut-off of water without notice. The CITY shall not be liable for its inability to
deliver water for any reason whatsoever.

10. The USER shall design and install its system so as to achieve a $40^{\circ} \mathrm{F}$ temperature drop throughout the load range between
the supply water and return water temperatures.

11. Seals installed on geothermal supply or return valves by the CITY must not be broken, tampered with or interfered with by
anyone other than the CITY's employees or agents.

12. The USER must permit access of CITY's employees or agents to its premises at all reasonable hours for purposes of inspection.

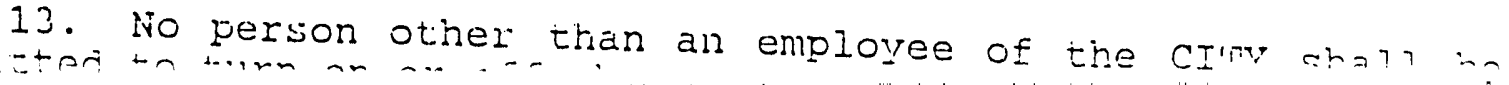


1. These rules and regulations become a part of each and everY GEOTHERMAL ENERGY CONNECTION AND SERVICE AGREEMENT (AGREEMENT) between the City of Klamath Falls, an Oregon municipal corporation (CITY) and users of geothermal water (USER) and may be changed at any time by the CITY upon due notice.

2. The privilege of the use of geothermal heat shall be conditioned upon a written and signed AGREEMENT.

3. No relocation of geothermal mains or taps will be made for any USER except upon agreement satisfactory to the CITY.

4. Changes or alterations in the USER's piping or fixtures wre not permitted during the period of any AGREEMENT, except upon the requirements of the CITY. The USER's system must conform to acceptable types of co CITY at all times. Diagrams illustrating purposes.

5. Upon request of CITY, CITY provided flow meters must be installed on USER's inlet piping, and meters shall be located as to provide access for convenient inspection by representatives of CITY
at reasonable hours.

6. No more than one building may be connected to any one service connection without written consent of the CITY.

purpose Use of the geothermal heat is not permitted for any purpose other than that specified in Exhibit "B" to the AGREEMENT.

8. The CITY is not responsible for the efficiency of any system supplied with heat from its mains, even though the CITY
grants the approval of its installation.

9. The CITY is not responsible for damage of any kind caused by the geothermal heated water or resulting from shut-off of water without notice. The CITY shall not be liable for its inability to
deliver water for any reason whatsoever.

10. The USER shall design and install its system so as to achieve a $40^{\circ} \mathrm{F}$ temperature drop throughout the load range between
the supply water and return water temperatures.

11. Seals installed on geothermal supply or return valves by the CITY must not be broken, tampered with or interfered with by anyone other than the CITY's employees or agents.

12. The USER must permit access of CITY's employees or agents to its premises at all reasonable hours for purposes of inspection.

12. No person other than an employee of the CI!Cy shall be permitted to turn on or off the water at CITY's valve installed on
USER's service line.

14. The CITY reserves the right to install any type of equipment or devices that it determines are necessary in the future including metering and measuring equipment within the USER's
premises.

15. The use of a booster pump or any device which will affect the pressure in the main supply lines of the CITY shall be approved
by CITY prior to installation. 

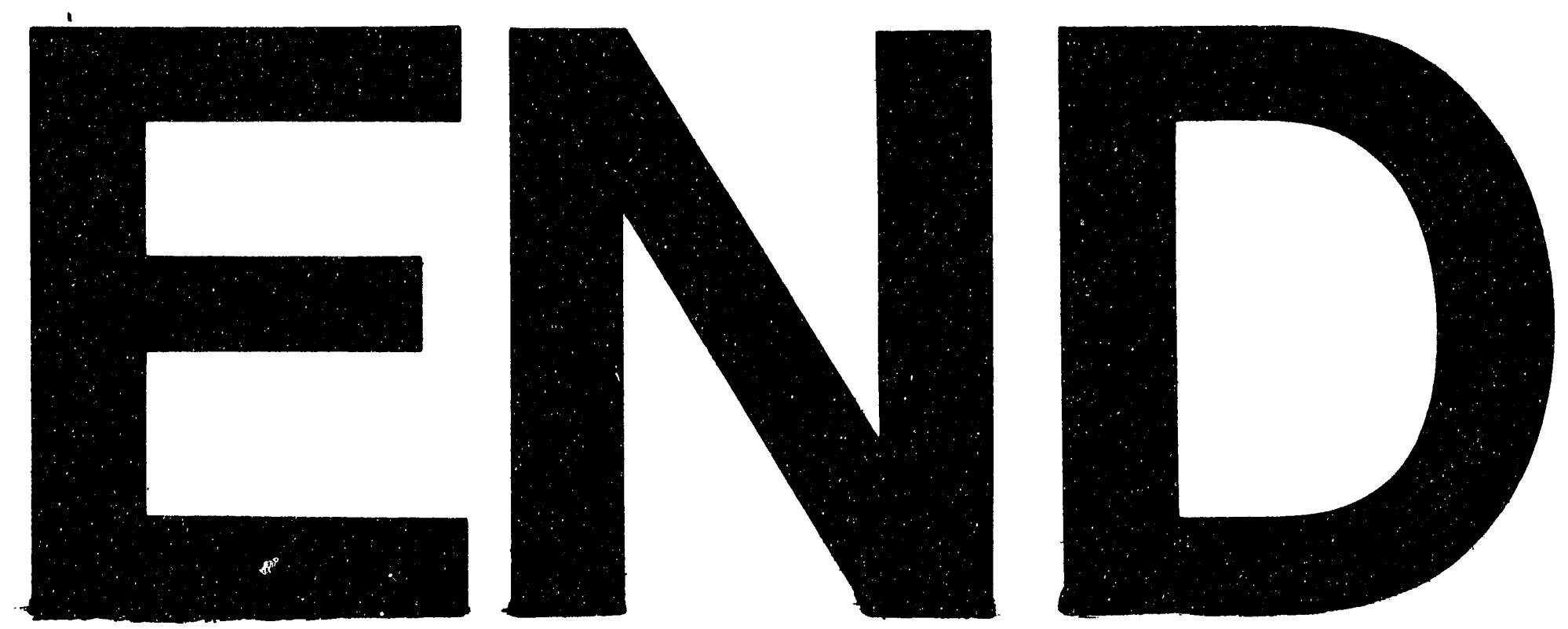

.
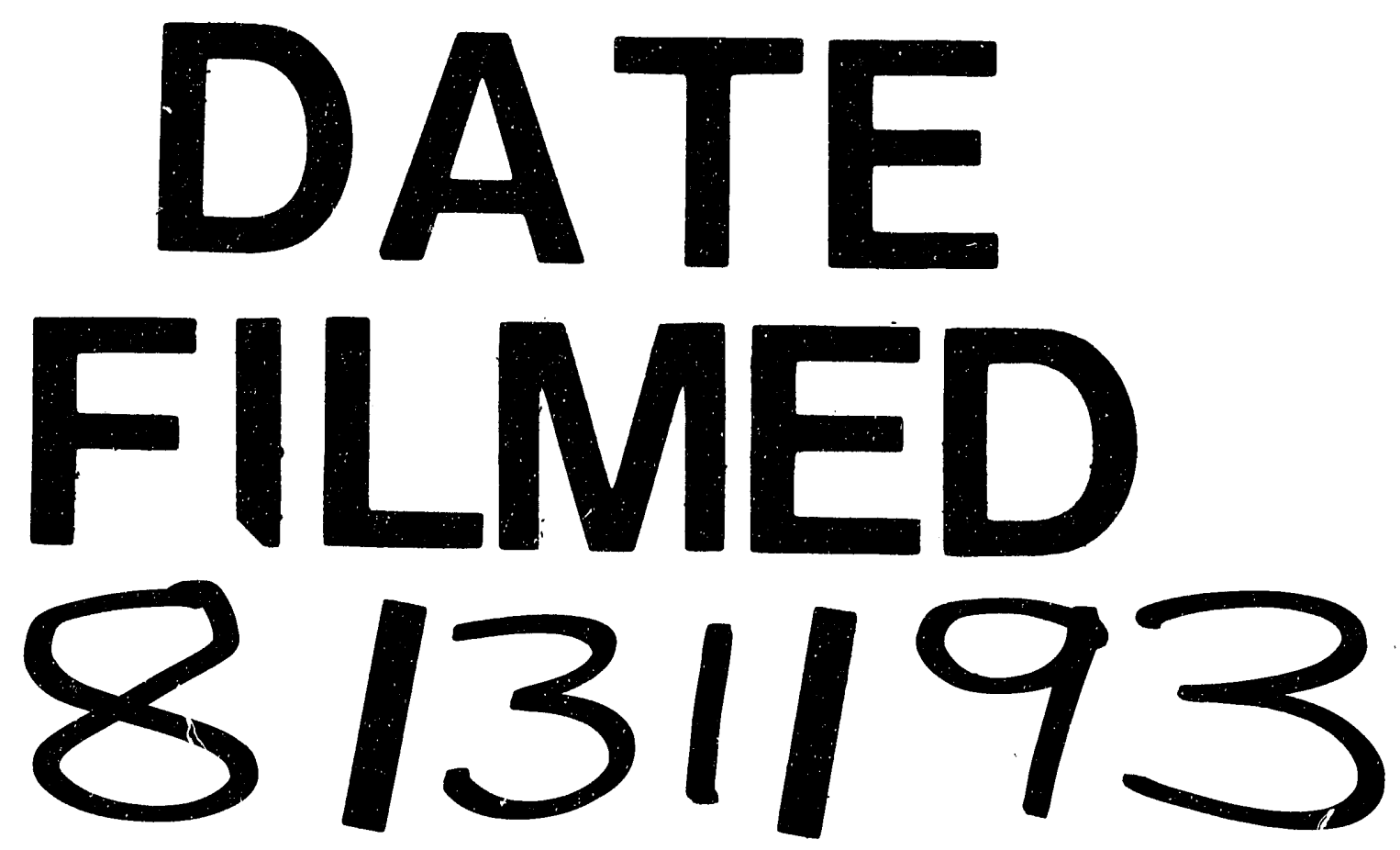

-1 
